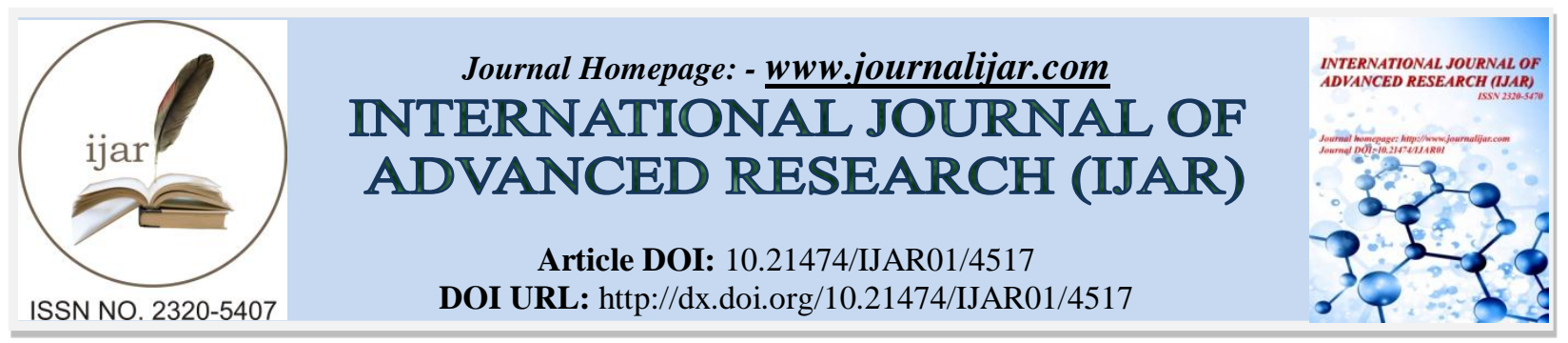

RESEARCH ARTICLE

\title{
EFFICACY OF BENOMYL AGAINST FUSARIUM OXYSPORUM F. CONGLUTINANS CAUSING
} YELLOWS OF KOHLRABI.

\author{
M. A. Sutar and S. S. Kamble.
}

Mycology and Plant Pathology, Research Laboratory, Department of Botany, Shivaji University, Kolhapur.

\section{Manuscript Info}

Manuscript History

Received: 18 April 2017

Final Accepted: 20 May 2017

Published: June 2017

Key words:-

Fusarium oxysporum. f.conglutinans,

kohlrabi, MIC

\section{Abstract}

There was variation in minimum inhibitory concentration (MIC)of benomyl among the 14 isolates Fusarium oxysporum. f.conglutinans (Wr.) Synder and Hansen. MIC on CDA plates ranged from $10 \mu \mathrm{g} \mathrm{ml}$ ${ }^{1}$ to $230 \mu \mathrm{g} \mathrm{ml}^{-1}$ and on kohlrabi plant $8 \mu \mathrm{g} \mathrm{ml}^{-1}$ to $150 \mu \mathrm{g} \mathrm{ml}^{-1}$. The isolate FOC-11 was highly resistant and isolate FOC-3 was highly sensitive.

Copy Right, IJAR, 2017,. All rights reserved.

\section{Introduction:-}

Kohlrabi (Brassica oleracea var.gongylodes L.) is an important vegetable crop grown in southern and northern part of India. Kohlrabi or Knol-khol or German turnip is a stout, round, tuberous, enlarged portion of stem. Kohlrabi is a perennial, cool season vegetable. It can be eaten raw as well as cooked. Leaves of kohlrabi are also edible. It is good source of minerals, vitamins and dietary fibers and negligible amount of fat and zero cholesterol. Leaves are very nutritious and rich in carotenes, minerals and vitamins A, K, C, and B-complex group. Kohlrabi is recommended to the patients of asthma and bronchitis. It is used to recover various diseases like liver diseases, stones in the urinary gallbladders, hemorrhoids, colitis, painful menstruation and anemia, cough, gout, rheumatism, arthritis, sciatica. Leaf juice is an excellent tonic for growing children.

This vegetable suffers from 'yellows of Kohlrabi' caused by Fusarium oxysporum $f$. conglutinans. The disease identified by yellowing, browning and withering of the leaves which progresses up in the plant. The first and most apparent symptom is dull green color of the leaves in the seed bed or in the field within a month after transforming. Young plant may be stunted, turn yellow and die rapidly. The lower leaves develop curling. The stem twisted towards one side.

Disease plants infected with Fusarium oxysporum $f$. conglutinans were collected from different localities of Maharashtra and Karnataka. (Belgum, Kolhapur, Sangli, Satara and Pune) in sterile polythene bags and were brought to laboratory. Fourteen isolates were obtained from these samples. These isolates were maintained on Czapek Agar medium. In vitro MIC of benomyl against 14 isolates was determined by food poisoning technique both in vitro and in vivo. (Dekker and Glelink, 1979). Plates were prepared with Czapek dox agar medium along with different concentrations of benomyl. Each fungal isolate was tested at different concentration of benomyl. The six day old culture was cut into $6 \mathrm{~mm}$ disc using cork borer and was placed on center of agar plate. These plate maintained under triplicate. Plates without fungicide served as 'control'. Plates were incubated for six days and linear growth of Fusarium oxysporum f. conglutinans was measured at different time intervals. 
In vivo sensitivity of Fusarium oxysporum $f$. conglutinans to benomyl was tested on Kohlrabi plants. For this experiment, healthy kohlrabi plants (60 days old) were used. These treated plants was inoculated with $50 \mathrm{ml}$ mycelial or spore suspension. This spore suspension was prepared using 6 day old culture of pathogen, in sterile distilled water and these suspension were poured in pot containing 3 plants. Percentage of infection was recorded after 7days by 0-4 scale (Kareem2007). Plant without treatment served as 'control' and plant without any treatment inoculation served as 'absolute control'.

Table 1:- MIC of benomyl against Fusarium oxysporum $f$. conglutinans isolates causing yellows of kohlrabi (in vitro and in vivo)

\begin{tabular}{|c|c|c|c|c|}
\hline Sr. No. & Locality & Isolate & In vitro $\left(\mu \mathrm{gml}^{-1}\right)$ & In vivo $\left(\mu \mathrm{gml}^{-1}\right)$ \\
\hline 1 & Belgaum & FOC-1 & 30 & 30 \\
\hline 2 & Sulaga & FOC-2 & 15 & 10 \\
\hline 3 & Muchandi & FOC-3 & 10 & 8 \\
\hline 4 & Kangrali & FOC-4 & 15 & 25 \\
\hline 5 & Bagewadi & FOC-5 & 100 & 70 \\
\hline 6 & Nesari & FOC-6 & 75 & 50 \\
\hline 7 & Amroli & FOC-7 & 25 & 15 \\
\hline 8 & Sangali & FOC-8 & 25 & 15 \\
\hline 9 & Shindewadi & FOC-9 & 50 & 35 \\
\hline 10 & Kesurdi & FOC-10 & 100 & 75 \\
\hline 11 & Kudal & FOC-11 & 230 & 150 \\
\hline 12 & Mangoan & FOC-12 & 150 & 80 \\
\hline 13 & Shevalwadi & FOC-13 & 25 & 12 \\
\hline 14 & Jejuri & FOC-14 & 50 & 50 \\
\hline
\end{tabular}

There was variation in MIC of benomyl among the 14 isolates of Fusarium oxysporum $f$. conglutinans MIC on Czapek dox agar medium range from $10\left(\mu \mathrm{gml}^{-1}\right)$ to $230\left(\mu \mathrm{gml}^{-1}\right)$ and on kohlrabi plants ranges from $\left(8 \mu \mathrm{gml}^{-1}\right.$ to $\left.150 \mu \mathrm{gml}^{-1}\right)$. FOC-3 was sensitive isolate while FOC-11 was resistant.

Many workers had reported benomyl resistance in different species of Fusarium (Thanassopoulous et al., 1970; Magie and Wilfret, 1974; Bollen, 1983; Molnar et al., 1985; Yasuda, 1986; Wada et al., 1990; Kamble and Gangawane, 1994 and Bhale, 2002).

Sensitivity of 14 isolates of Fusarium oxysporum $f$. conglutinans to benomyl from different localities showed variation when examined in in vitro and in vivo. Isolate FOC-3 was sensitive and FOC-11 was highly resistant to benomyl. In vitro MIC ranges from $10\left(\mu \mathrm{gml}^{-1}\right)$ to $230\left(\mu \mathrm{gml}^{-1}\right)$ and on kohlrabi plants ranges from $\left(8 \mu \mathrm{gml}^{-1}\right.$ to 150 $\left.\mu \mathrm{gml}^{-1}\right)$.

\section{References:-}

1. Bhale, U. N. (2002): Studies on management of some important diseases of spinach in Maharashtra. Ph.D. Thesis, Dr. Babasaheb Ambedkar Marathawada University, Aurangabad

2. Bollen, G.J. (1982): Fungicide resistance and microbial balance and fungicide resistance in crop protection (Dekker J. and S.G. Georgopoulos, Eds.).C.A.P.D.165

3. Dekker, J. and Gielink, A. J. (1979): Acquired resistance to pimaricin in Cladosporium cucumerinum and Fusarium oxysporum f. sp. Narcissi associated with decreased virulence Neth. J. P1. Path.85: 67-73.

4. Kamble S.V. and Gangawane, L.V. (1994): Effect of passage on the development of benomyl resistance in Fusarium udum in vitro. Indian Phytopath.47(3): 354.

5. Kareem(2007): Induced resistance in bean plants against Root rot and Alternaria leaf spot diseases using biotic and abiotic inducers under field condition. Research journal of Agriculture and Biological Science, 3(6):767774.

6. Magie, R. O. and G. J. Wilfret (1974): Tolerance of Fusarium oxysporum f. sp. gladioli to benzimidazole fungicide. Plant Dis. Reptr. 58: 256-259.

7. Molnar, A., L. Hornok and Resti, M. (1985): The high level of benomyl tolerance in Fusarium oxysporum is determined by the synergistic interaction of two games. Extl. Mycol. 9: 326-333. 
8. Thanassopoulos, C.C., Giannopolitis, C.N. and Kitsos, G. T. (1970): Evaluation of sensitiveness and development of resistance of Fusarium oxysporum f. sp. lycopersici to benomyl. Journal of Phytopathology. 70 (2): 114-120.

9. Wada, T., Kuzuma, S. and Takenaka, M. (1990): Sensitivity of Fusarium moniliformae isolates to pefurazoate. Ann. Phytopathol. Soc. Jpn. 56: 449-456.

10. Yasuda, Y. (1986): ISSP Chemical Control Newsletter, U. K. 7: 8-9. 